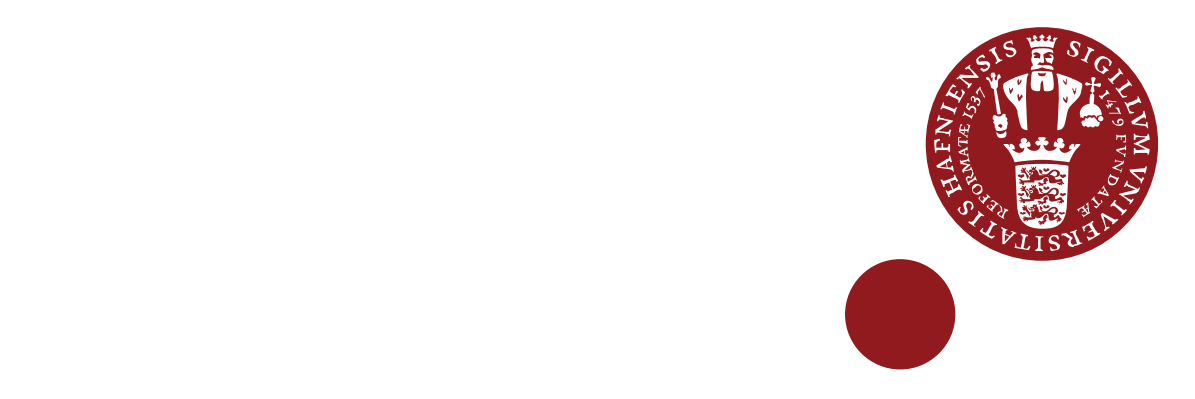

\title{
iCourts
}

iCourts Working Paper Series, no. 226, 2020

\section{Judicial and Extra-Judicial Review: The Quest for Epistemic Certainty}

\begin{abstract}
Michał Krajewski
Forthcoming in Merijn Chamon, Mariolina Eliantonio, Annalisa Volpato (eds), The Boards of Appeal of EU Agencies: A New Paradigm of Legal Protection? (forthcoming in Oxford University Press 2021).

iCourts - The Danish National Research Foundation's Centre of Excellence for International Courts
\end{abstract}




\begin{abstract}
Boards of appeal have been set up in some EU agencies to offer legal protection attuned to regulatory fields requiring specialist knowledge. They also moderate the number of technically or scientifically complex cases reaching the generalist EU Courts. However, litigants have recently called in question the limited extent to which boards of appeal delve into contentious empirical appraisals adopted by EU agencies. Do the boards of appeal fulfil the hopes placed in them by exceeding EU judicial review capacities? This paper explores the review technique of the EU Courts and several boards of appeal employed in empirically complex cases decided between 2014 and 2018. It argues that neither the EU Courts nor the boards of appeals can perform a fully autonomous and exhaustive check of the contested empirical appraisals. Due to their institutional and procedural features, they struggle with epistemic uncertainty in regulatory fields in which decisions must be made despite persisting data gaps or the lack of rigorous scientific or technical methodologies. The judicial or extra-judicial review reaches only as far as the applicants themselves can prove the certainty of their scientific or technical assertions against those of the challenged EU institutions or agencies. This conclusion leads to fundamental questions regarding the rule of law's requirements in relation to the contentious and uncertain empirical basis of a growing number of EU legal acts and the normative functions of EU judicial and extra-judicial review.
\end{abstract}

KEYWORDS: EU Courts - Court of Justice - General Court - board of appeal - judicial review administrative review - extra-judicial review - empirical uncertainty - administrative discretion technical discretion - action for annulment - administrative appeal - the standard of review - the intensity of review - adversarial model - inquisitorial model - the rule of law - effective judicial protection

Michal Krajewski, Postdoctoral Research Fellow, University of Copenhagen, $i$ Courts Centre of Excellence for International Courts

Email: Michal.krajewski@jur.ku.dk 
This research is funded by the Danish National Research Foundation Grant no. DNRF105.

iCourts - Centre of Excellence for International Courts - focuses on the ever-growing role of international courts, their place in a globalizing legal order, and their impact on politics and society at large. To understand these crucial and contemporary interplays of law, politics, and society, iCourts hosts a set of deeply integrated interdisciplinary research projects on the causes and consequences of the proliferation of international courts.

iCourts opened in March 2012. The centre is funded by a large grant from the Danish National Research Foundation (for the period 2012-18). 


\section{Michał Krajewski ${ }^{1}$}

\section{Introduction}

For public lawyers, judicial review epitomises the rule of law and legal protection against potentially unlawful acts of public authorities. The ideal of the rule of law at the EU level has been equated with a 'complete system' of procedures for the judicial review of EU legal acts. $^{2}$ A fundamentally contested concept as it is, the rule of law implies a binding of public authorities with objectively ascertainable legal norms to minimise the risk of arbitrariness.

However, the natural language in which legal norms are expressed cannot always keep up with the changing reality. The law often leaves public authorities discretion to decide which empirical factors are relevant in a given case and how they should be assessed (technical discretion). The law may also leave discretion as to the choice of substantive values which will guide the exercise of authority (political discretion). Judicial and extra-judicial review mechanisms such as courts, administrative boards of appeal and ombudsmen, may be perceived as a second step in the process of elaborating a specific administrative decision or regulation. Rather than second-guessing technical and political choices, thereby restraining administrative discretion, review mechanisms may be conceived of as co-operating with administration, helping the latter to frame and orient the exercise of discretion by reference to ascertainable legal norms. Thanks to judicial or extra-judicial review, legal acts may be more responsive to a wide range of affected interests and reasoned arguments. ${ }^{3}$

The quest for structuring discretion and minimising the risk of arbitrariness in the exercise of public authority through judicial review encounters institutional and procedural obstacles. Generalist judges may have no sufficient expertise to autonomously assess

\footnotetext{
${ }^{1}$ Postdoctoral Research Fellow, University of Copenhagen, iCourts Centre of Excellence for International Courts. I am grateful for the feedback I received from the participants and organisers of the workshop 'The Boards of Appeal of EU Agencies' (Maastricht University, Campus Brussels, 21-22 September 2020). A revised version of this working paper will be published in Merijn Chamon, Mariolina Eliantonio, Annalisa Volpato (eds), The Boards of Appeal of EU Agencies: A New Paradigm of Legal Protection? (forthcoming in Oxford University Press 2021).

${ }^{2}$ Case 294/83 Les Verts, para 23.

${ }^{3}$ Joana Mendes, 'Bounded Discretion in EU Law: A Limited Judicial Paradigm in a Changing EU' (2017) 80 Modern Law Review 443-72, 462.
} 
whether all relevant and intricate factors have been considered in establishing the empirical basis of impugned legal acts, and whether correct conclusions have been drawn from these factors. Also, courts may be constrained in their fact-finding by tight procedural frameworks aimed at accommodating conflicting objectives such as the satisfactory quality of decision-making and the parties' right to be heard with the need to keep the time and cost of proceedings reasonable.

The judges of the EU Courts do not specialise in specific areas and operate within a largely adversarial procedural framework. They struggle especially with socio-economic, technical, and scientific appraisals increasingly underpinning EU legal acts. ${ }^{4}$ They also adopt a passive approach to fact-finding, possibly increasing deference towards uncertain and contentious empirical statements accepted as accurate by EU institutions and bodies. ${ }^{5}$

Especially the General Court (EGC), which deals with actions for judicial review by private parties as a first instance, must increasingly delve into regulatory fields requiring specialist knowledge, such as the environmental and public health protection or financial supervision. ${ }^{6}$ The critical issues are not only the sheer number and intricate nature of empirical factors but also the uncertainty about the accuracy of data and the validity of empirical assumptions and inferences. ${ }^{7}$ More often than not, scientific data or technical knowledge point to divergent conclusions. Administrators must decide based on controversial assumptions, approximations, and predictions. In lack of established and rigorous methodologies, they must rely on a not always verbalised 'gut feeling', acquired

\footnotetext{
${ }^{4}$ Ellen Vos, 'The European Court of Justice in the Face of Scientific Uncertainty and Complexity' in Mark Dawson, Bruno de Witte and Elise Muir (eds), Judicial Activism at the European Court of Justice (Edward Elgar 2013), 143. The complexity and volume of casefiles is one of the factors that most frequently affect the duration of the case. European Court of Auditors, 'Special Report: Performance review of case management at the Court of Justice of the European Union' (14/2017), 33.

${ }^{5}$ Eric Barbier de la Serre and Anne-Kuse Sibony, 'Expert Evidence Before the EC Courts' (2008) 45 Common Market Law Review 941-85. Alexander Fritzsche, 'Discretion, Scope of Judicial Review and Institutional Balance in European Law' (2010) 47 Common Market Law Review 361-403. AG Jacobs, Case C-269/90 Technische Universität München, para 13.

${ }^{6}$ ECJ, 'Annual Report - Judicial Activity 2018', 161.

${ }^{7}$ Lucinda Vandervort, 'Empirical Uncertainty and Legal Decision-Making' in Eugenio Bulygin, Jean Louis Gardies, Ilkka Nilniluoto (eds), Man, Law and Modern Forms of Life (D. Reidel Publishing) 251-261.
} 
following years of practical experience but also underpinned by deeply-held subjective value-judgments.

This empirical uncertainty relates even to legal conditions and guiding standards for administrative action. ${ }^{8}$ Such conditions and standards are often expressed with open-ended concepts such as 'threats to public health', 'financial stability', or 'proportionality'. Empirical uncertainty is, therefore, enmeshed with normative uncertainty. Before decision-makers decide which empirical factors fall into the category of, for instance, 'threats to public health', they must construe an abstract idea of such threats, which depends on they axiological convictions, i.e. how they choose to strike a balance between competing interests and values at stake. ${ }^{9}$ For instance, while assessing equally reliable but at least partly divergent data on a chemical substance, those deciding on its safety are likely to be influenced by their subjective preference for either the precaution for public health or the business rights of the affected industry. An uncontroversial and universal 'burden of proof' in such cases seems unattainable.

It is sometimes argued that the adjudicators should scrutinise only whether technical discretion has been 'correctly' exercised and, on the contrary, defer to political discretion. In this view, the adjudicators should be able to analytically disentangle the two types of discretion somehow, ${ }^{10}$ or at least be able to identify cases in which a controversial empirical appraisal is underpinned by a normative or political appraisal, which may require deference due to the lack of exact legislative prescription. ${ }^{11}$ It has also been argued, however, that a distinction adopted in many legal orders between technical discretion (a matter of objective cognition or verifiable empirical appraisals) and political discretion (a matter of volition or

\footnotetext{
${ }^{8}$ Mendes (n. 3).

9 Regarding a somewhat narrower conception of normative uncertainty see, Matthias Klatt and Johannes Schmidt, 'Epistemic discretion in constitutional law' (2012) 10 International Journal of Constitutional Law 69-105.

${ }^{10}$ For instance, Mirko Prek and Silvère Lefèvre, '“Administrative Discretion", "Power of Appraisal” and "Margin of Appraisal" in Judicial Review Proceedings Before the General Court' (2019) 56 Common Market Law Review 339-80, 348.

11 The EU judges may not always be able to detect the entangement of technical and political discretion, Giulia C Leonelli, 'The fine line between procedural and substantive review in cases involving complex technical-scientific evaluations: Bilbaína' (2018) 55 Common Market Law Review 1217-50.
} 
subjective normative appraisals) appears artificial. ${ }^{12}$ The entanglement of different types of discretion in practice makes judicial or extra-judicial review an even more difficult task.

How to review scientific or technical questions to which there is no single right or wrong answer if, moreover, the applicable legal framework offers scarce normative guidance? Unlike specialised administration, the EU Courts do not have experts, recognised methods, advisory committees, delegated national experts, and the like. ${ }^{13}$ Constrained by the adversarial procedure, they usually examine the claims and evidence adduced by the parties, relinquishing their own investigatory powers. ${ }^{14}$

Boards of appeals (the 'BoAs') were supposed to fill this gap. Composed of legally and technically qualified members alike, they should be well-equipped to deal with cases characterised by an entanglement of empirical and normative uncertainty. Organisationally attached to the respective agencies, they should have access to relevant expertise and resources. Under due process theories, notably, procedural safeguards at the (formally) administrative stage of decision-making, such as specialised and independent administrative review, may compensate for subsequently deferential judicial review. ${ }^{15}$

Do the BoAs live up to expectations? Recently, the EGC dismissed an action by a significant chemical operator who claimed that the standard of review employed by the BoA of the European Chemical Agency (the 'ECHA') was not sufficiently thorough. In this case, the EGC struggled with highly ambiguous legislative provisions regarding what the ECHA BoA's scope of responsibility is. It ultimately confirmed that the ECHA BoA might defer to uncertain scientific assessments endorsed by national experts gathered within the ECHA main decision-making committee. Likewise, litigants recently contested deferential review practised by the BoA of the Agency for the Cooperation of Energy Regulators (the 'ACER'). This BoA has consistently invoked legal deadlines imposed upon its review proceedings

\footnotetext{
${ }^{12}$ Mendes (n. 3). Joana Mendes, 'Discretion, Care and Public Interest in the EU Administration: Probing the Limits of Law' (2016) 53 Common Market Law Review 419-52.

${ }^{13}$ Hans Peter Nehl, 'Judicial Review of Complex Socio-Economic, Technical and Scientific Assessments in the European Union' in Joana Mendes (ed), EU Executive Discretion and the Limits of Law (Oxford University Press 2019).

${ }^{14}$ René Barents, 'EU Procedural Law and Effective Legal Protection' (2014) 51 Common Market Law Review 1437-62.

${ }^{15}$ Renato Nazzini, 'Administrative Enforcement, Judicial Review and Fundamental Rights in EU Competition Law: A Comparative Contextual-Functionalist Perspective' (2012) 49 Common Market Law Review 971-1006.
} 
and the complexity of cases to justify deferential review. ${ }^{16}$ In an earlier case, on the contrary, the ECJ upheld an action against the BoA of the Common Plant Variety Office (the 'CVPO') requiring it to perform a more searching review, akin to the full review performed by the BoAs of the EU Intellectual Property Office (the 'EUIPO'). ${ }^{17}$

This paper explores the review technique of BoAs which deal with a high level of empirical and normative uncertainty magnified by voluminous case files. It mainly inquires into the practice of the ECHA BoA, due to its considerable output. It also examines the hitherto limited output of the BoAs of the European Supervisory Authorities (the 'ESAs'), the European Aviation Safety Agency (the 'EASA'), the ACER, and the Appeal Panel of the Single Resolution Board (the 'SRB'). ${ }^{18}$ It compares the review technique employed by these BoAs and the EGC. ${ }^{19}$ To this end, a cluster of EGC annulment judgments ${ }^{20}$ has been identified relating to legal acts bearing similarities to the acts with which the said BoAs deal, in terms of the subject-matter and the level of uncertainty, in the following regulatory fields: the risk regulation of chemicals, pharmaceuticals, food safety, aviation safety and financial supervision. The analysis covered the BoA and EGC cases in which these bodies - or higherinstance bodies - issued a definitive decision or ruling between 2014 and 2018 (over five years). ${ }^{21}$ This way, only the final results of cases were analysed. The analysis included pleas in law (allegations) relating to possibly inaccurate empirical determinations or erroneous

${ }^{16}$ ACER BoA, Case A-001-2019 Amprion E Transnet, paras 74-81.

17 Case T-133/08 Schräder v CPVO and Case C-546/12 P Schräder v CPVO.

18 The EUIPO and CPVO BoAs, not included in the study, do not seem to deal with the same level of uncertainty and, at any rate, their cases are less voluminous and not involving controversial choices between different types of private and public interests (such as the interests of the affected industry and the protection of the environment or public health).

19 The appeals to the ECJ are formally limited to the points of law but a point of law may also be a manifest error of empirical assessment by the EGC, which gives to the ECJ leeway in moderating the intensity of its appellate review, Giulia Gentile, 'The ECJ as the EU Court of Appeal: some evidence from the appeal case-law on the non-contractual liability of the EU' (2020) 13 Review of European Administrative Law 73-107. However, the ECJ rarely engages with complex scientific or technical matters on appeal in a meaningful way.

${ }^{20}$ Relating to the Article 263(4) TFEU action for annulment.

${ }^{21}$ The criterion for including a BoA and EGC case in the analysis was, in other words, the date of the decision or ruling definitely closing the case (by the BoA, the EGC or the ECJ, depending on whether there were subsequent annulment actions and appeals in the case). Each BoA decision can be challenged before the EGC, and the resulting EGC rulings can be challenged before the ECJ. Also, the EGC rulings not relating to BoA decisions can be challenged before the ECJ. 
legal assessments of uncertain empirical factors, as well as errors of normative assessment (proportionality or adequacy of the impugned measures). ${ }^{22}$ The analysis has also exceptionally included the ACER BoA regarding energy markets closed in 2019, as too few cases were closed prior to this year. ${ }^{23}$

The paper argues that the evolving technique of judicial and extra-judicial review requires a bottom-up analysis rather than an application of established domestic or comparative concepts (Section 2). Following this approach, the review technique of the EU Courts and the BoAs has turned out comparable. The BoAs have transplanted conceptual tools and procedural solutions developed within the EU judicial review. Equipped with modest resources, the boards of appeal confine themselves to examining the pleas and evidence adduced by the parties (Section 3). During the examined period, the EGC tended not to delve into the details of scientific opinions made by independent expert committees. It more readily scrutinised economic assessments of EU institutions (Section 4). On the contrary, the ECHA BoA directly engaged with methodological subtleties of intricate chemical studies. However, it deferred to first-instance decision-makers in the face of unsolvable empirical uncertainty. Neither could the remaining BoAs avoid deference faced with epistemic uncertainty, invoking also limited time and resources (Section 5). These findings contrast with a view regarding an entirely disparate nature of judicial and administrative review, ${ }^{24}$ which may serve to justify the two-tier review system. They also lead to fundamental questions regarding the rule of law's requirements in relation to the contentious and

${ }^{22}$ With regard to the protection of public health and the environment, twenty-five annulment cases were identified, in which the EGC scrutinised the accuracy of uncertain empirical and normative appraisals under the heading of 'manifest error of asessment', 'proportionality', or similar, as well as twenty ECHA BoA cases fulfilling analogous criteria. Individual annulment cases relating to aviation safety and financial supervision, and a handful of cases before the remaining BoAs, were also identified. The analyses does not relate to other pleas in law such as those relating to a formal competence to issue a measure, procedural requirements, a correct interpretation of applicable legal requirements, observance of general principles such as equal treatment or legal certainty, an adequate statement of reasons, an abuse of power, and an error of assessment with regard to ordinary factual circumstances (not raising epistemic problems).

${ }^{23}$ However, no EGC cases pertaining to energy markets and satisfying the relevant criteria were identified.

24 The EGC held that the EUIPO BoAs are formally not judicial bodies, so one cannot rely on a right to a fair trial before them. Case T-63/01 Procter and Gamble v OHIM, paras 22-23. See also, the concept of 'continuity in terms of functions' between the agency and its BoA, Case C-29/05 P OHIM v Kaul, paras 56-57. Case T-672/17 Mamas and Papas v EUIPO, para 39. Case T-177/16 Mema v CPVO, paras 39-42. 
uncertain empirical basis of a growing number of EU legal acts and a deeper normative rationale of EU judicial and extra-judicial review (Section 6).

\section{The Evolution of Judicial and Extra-Judicial Review in Response to Epistemic Uncertainty}

A popular endeavour within the EU legal scholarship has been to examine whether newly emerging forms in which authority is exercised at the EU level can be subject to comprehensive judicial review. Is all-encompassing supervision by the EU Courts a necessary prerequisite for the rule of law? In general, a deeper normative rationale of judicial review is that it minimises the risk of arbitrariness. However, judicial review must continuously adjust to the changing nature of EU legal acts. ${ }^{25}$ In some EU Member States, administrative courts have elaborated more thorough review techniques to deal, for instance, with complex environmental law cases. ${ }^{26}$ In other Member States, more specialised review mechanisms have been developed. ${ }^{27}$

In some theoretical accounts, importantly, judicial review is not seen as entirely separate from prior forms of legal protection or review. Judicial review may instead be considered a culmination of a broader governance process involving several administrative and, subsequently, judicial stages. Some forms of independent scrutiny at a formally administrative stage might justify subsequent judicial deference to, for instance, uncertain empirical and normative appraisals. ${ }^{28}$ At the same time, formally extra-judicial forms of

\footnotetext{
${ }^{25}$ A judge of the EGC admitted that the more economic approach of the Commission in competition law cases at first constituted a challenge for the judges, Nicholas Forwood, 'The Commission's More Economic Approach - Implications for the role of the EU Courts, the treatment of economic evidence and the scope of judicial review', European Competition Law Annual: Evaluation of evidence and its judicial review in competition cases (2009).

${ }^{26}$ Marc Clément, 'La jurisprudence administrative en droit de l'environment, entre technique et acteurs' (2019) 19 Revue juridique de l'environnement 51.

${ }^{27}$ Mark Elliott and Robert Thomas, 'Tribunal Justice and Proportionate Dispute Resolution' (2012) 71 Cambridge Law Journal 297-324.

${ }^{28}$ Nazzini (n. 15).
} 
review might help minimise the risk of arbitrariness in the areas with which judicial forms are ill-equipped to deal..$^{29}$

Are the EU boards of appeal tailor-made forms of specialised review supplementing the judicial review by the EU Courts? A bottom-up analysis of their practice is necessary to answer this question. It is also necessary to keep critical distance towards domestic normative concepts and comparative analytical insights, relating to specific institutional contexts and legal traditions, which may not match those of the EU. ${ }^{30}$ Certain domestic systems of administrative law distinguish between the review of 'legality', exercised by courts, and the review of 'merits' or 'expediency', exercised by hierarchically superior or quasi-judicial administrative bodies. Legality review pertains to the conformity of contested acts with applicable legal norms only, whereas merits review may also encompass the conformity with extra-legal criteria (such as scientific standards or policy considerations). At the same time, it is considered that administrative review tends to favour the policy goals, while judicial review focuses on individual rights. ${ }^{31}$

Considering their court-like features, Craig classifies the BoAs as a subset of the EU-level judiciary. ${ }^{32}$ At the same time, the EU law-makers have been far from clear in defining their mandates. The BoAs appear as legal experiments. They have hammered out in practice the detailed scope and intensity of the review they perform, considering legal mandates and pragmatic considerations alike, such as modest resources and the complexity of regulatory fields characterised by epistemic uncertainty.

The question about the actual added value of the review by the BoAs in relation to the EU judicial review is essential as the EU Courts have improved their review technique over the

\footnotetext{
${ }^{29}$ Mendes (n. 3), 469.

${ }^{30}$ Filipe Brito Bastos, 'Doctrinal Methodology in EU Administrative Law: Confronting the Touch of Stateness', forthcoming in German Law Journal 2021.

${ }^{31}$ Peter Cane, 'Judicial Review and Merits Review: Comparing Administrative Adjudication by Courts and Tribunals' in Ssusan-Rose Ackerman and Peter Lindseth (eds), Comparative Administrative Law (Edward Elgar 2018). Having scrutinised the legal frameworks of the BoAs and their interpretation, however, Chirulli and de Lucia concluded that the BoAs demonstrate features characteristic to the ideas of both administrative implementation of policy goals and the adjudication of rights. Paola Chirulli and Luca de Lucia, Rimedi amministrativi ed esecuzione diretta del diritto europeo (Giappichelli Editore 2018).

32 Paul Craig, 'Courts' in Paul Craig (ed), EU Administrative Law (OUP 2018).
} 
last decades. They have elaborated a set of substantive and procedural principles of administrative law (such as the duty of care and to state comprehensive reasons, impartial and objective investigation of facts, proportionality) as well as concepts governing the judicial review (such as manifest error of assessment). These principles and tools enable the EU judges to engage with intricate and uncertain appraisals meaningfully. They are formally geared towards controlling the process of decision-making and justifying the decision (process-oriented review). The assumption is that thorough review of the process may compensate for the lack of a direct engagement with the substance. ${ }^{33}$ However, it still remains unclear to what extent the process-oriented review technique achieves its declared goals, ${ }^{34}$ especially in cases characterised by normative and empirical uncertainty.

The thoroughness of judicial or extra-judicial review may be significantly affected by empirical and normative uncertainty, especially in cases relating to the protection of public health and the environment. According to the precautionary principle, EU bodies may adopt measures aimed at the protection of public health and the environment even in the face of persisting uncertainty as to the existence of risk or adequacy of the measure. ${ }^{35}$ In other words, the precautionary principle moderates the required burden of proof which the EU institutions and bodies need to justify limitations to, for instance, certain business rights. ${ }^{36}$ By the same tokens, judges and other adjudicators may tend to favour the public interests protected by the precautionary principle. At any rate, a balancing between values such as business rights and public health, while determining the appropriate degree of certainty for EU institutions and bodies to act, is discretionary and prone to individual axiological preferences.

In line with the original assumption, the mixed legal-technical composition should enable the BoAs to perform more searching and balanced review. However, the examined BoAs have generally transplanted the largely adversarial procedural model based on the examination of partisan evidence, the process-oriented technique of EU judicial review, and

\footnotetext{
33 See the review of case law in Mendes (n. 12), 427-434. This author argues that the duty of care should be extended to normative appraisals (political discretion) by the EU institutions and bodies.

${ }^{34}$ Andrew Woodhouse, 'Process review as panacea: a critique of process review advocacy in the European Union' (2020) 45 European Law Review 373-95.

35 Paul Craig, 'The Precautionary Principle' in Paul Craig (ed), EU Administrative Law (Oxford University Press 2018).

${ }^{36}$ For instance, Case T-115/15 Deza v ECHA, paras 172-174.
} 
the practice of deference towards uncertain appraisals. Nonetheless, the BoAs may go at great lengths in pro-actively clarifying contentious empirical issues to minimise the degree of remaining epistemic uncertainty, through in-depth and reasoned deliberation with the parties. The BoAs generally operate within less rigid procedural schemes. They also specialise in single, relatively coherent types of litigation. Further evolution of their review technique may hinge upon available resources for independent fact-finding, supporting staff, or even broader composition, instead of the wording of abstract legislative mandates.

The analysis of the judicial and extra-judicial review technique in the following sections is structured around three parameters: the subject matter of review, the procedural burden of proof, and the level of engagement with the contested empirical and normative appraisals. These parameters are intended to circumscribe the review practice by defining its outer limits, without using unsuitable concepts from different domestic contexts or those introducing a purely semantic difference. The following section examines the subject-matter of review proceedings before the EU Courts and the BoAs (how and by whom the subjectmatter is defined ${ }^{37}$ ) and the procedural burden of proof (who takes the initiative for adducing relevant evidence during the proceedings ${ }^{38}$ ). Subsequently, the remaining sections examine the level of engagement with the contested empirical and normative appraisals by the adjudicators ${ }^{39}$ based on the reasoning provided in their decisions and rulings.

\section{Procedural Model: A Silent Arbiter or an Active Inquisitor?}

The EU Courts are directly called to review uncertain empirical issues and discretionary normative choices of EU institutions and bodies within the Article 263 TFEU action for annulment. ${ }^{40}$ An essential feature of this avenue is the so-called 'system of pleas'. In this

\footnotetext{
${ }^{37}$ How formalist is the definition of the subject matter? Can the subject matter be modified, broadened or a mistake in this respect be corrected at a later stage of review proceedings?

${ }^{38}$ Who must discharge the burden of proof within the review process by providing or indicating the evidence supporting or opposing the contested measure? How active is the review body in terms of fact-finding?

${ }^{39}$ Who retains the last word as to matters raising problems of epistemic uncertainty or relating to political discretion: the administration, the adjudicator or a third party such as an autonomous expert committee or expert witness?

40 Occasionally, the ECJ is called to review the validity of EU legal acts underpinned by complex assessments within the Article 267 TFEU preliminary reference procedure.
} 
procedural system, the applicant defines the subject-matter of proceedings in the initial application and, in principle, cannot modify or broaden the subject-matter at a later stage. The subject-matter includes the unequivocally indicated legal act which is challenged, the specific aspects of its substance or the process leading to its adoption which are to be reviewed, as well intelligible and persuasive arguments as to why and how these elements breach applicable legal norms, i.e. the so-called pleas in law. ${ }^{41}$ A lack of clarity regarding these elements results in the rejection of the action. In principle, the applicants cannot raise new pleas in law in the course of proceedings, but they may 'amplify' the pleas which have been already raised. The judges may also depart from specific arguments invoked by the applicants in support of their pleas. ${ }^{42}$ Still, there is a risk of an objectively unlawful legal act being upheld, if the applicant - or rather her legal representative - makes a procedural mistake. Neither can the judges raise new pleas in law on their own motion, except for certain procedural or competence-related pleas that are deemed to be of public interest (such as, most importantly, a plea relating to an inadequate statement of reasons). ${ }^{43}$

The EU Courts have transplanted this relatively formalist procedural system and practice from the procedural law of French administrative courts. Other systems for the judicial review of administrative action across the EU adopt different solutions, according to which administrative courts are limited by the subject-matter indicated by the applicant to a lesser extent. Such courts must proactively seek objective truth rather than only decide on which of the parties have advanced better legal arguments and adduced more persuasive evidence, or expect the applicant to indicate gaps in the evidence relied on by the challenged administration. ${ }^{44}$ A more inquisitorial system of administrative justice requires more

\footnotetext{
${ }^{41}$ As indicated in Article 263(4) TFEU, the pleas in law may relate to the competence, procedure, substance or the 'abuse of power'. René Barents, EU Remedies and Procedures (Wolters Kluwer 2016), 618.

${ }^{42}$ Michał Krajewski, 'The Many-Faced Court: The Value of Participation in Annulment Proceedings' (2019) 16 European Constitutional Law Review 220-46, 227-32.

${ }^{43}$ Freya Clausen, Les moyens d'ordre public devant la Cour de justice de l'Union européen (Bruylant 2018).

${ }^{44}$ For instance, the German administrative courts are bound to assess the legality of impugned acts not only on the basis of pleas explicitly put forward by an applicant but in light of all rules that they deem applicable to the case. Moreover, they are required to carry out all necessary factual investigations on their own motion. M. Eliantonio, Europeanisation of Administrative Justice? The Influence of the ECJ's Case Law in Italy, Germany and England (Europa Law Publishing 2009), 16061 and 97. In Poland, on the one hand, the administrative courts are obliged to raise all relevant pleas in law on behalf of
} 
resources and implies more power and responsibility on the side of the courts, or another kind of adjudicative bodies, vis-à-vis the primary decision-makers. ${ }^{45}$

The system of pleas does not unambiguously follow from the black-letter of EU procedural law but, arguably, it has been an interpretive choice made by the ECJ in its early days. It discharges several functions. It facilitates the equal hearing of both parties and increases the efficiency of proceedings as it requires putting all the cards immediately on the table. Consequently, it moderates the costs and time of proceedings, avoiding the risk of repeating procedural stages in case of new pleas being raised during the ongoing proceedings. It also reflects a conception of the allocation of authority to the primary decision-makers and the reviewers. The latter do not repeat the whole decision-making process in view of reaching the best possible solution but focus on specific problems indicated by the applicant. ${ }^{46}$ On the contrary, the system of pleas has been criticised by Barents who sees it as overly rigid and sometimes preventing the EU judicature from getting to the bottom of the legal problem before it due to an error of the applicant's lawyer. ${ }^{47}$

The procedural law of the EU Courts leaves the judges considerable discretion as regards obtaining relevant evidence. The parties are supposed to provide or indicate the evidence in their initial pleadings along with the pleas in law. The EGC autonomously assesses if it needs further evidence. ${ }^{48}$ In practice, the EGC remains passive about fact-finding, despite having at its disposal extensive procedural rules regarding expert witnesses and reports, ${ }^{49}$

the applicant who might remain completely passive during the proceedings. On the other hand, the administrative courts are forbidden from second guessing any factual determinations or even from taking evidence.

${ }^{45}$ Mirjan R Damaška, The Faces of Justice and State Authority: A Comparative Approach to the Legal Process (Yale University Press 1986) distinguishes between the policy enforcement function (the inquisitorial model) and dispute settlement function (the adversarial model) of justice.

${ }^{46}$ Krajewski (n. 42).

${ }^{47}$ Barents (n. 14).

48 According to the well-established case law, the EGC 'is the sole judge of any need to supplement the information available to it in respect of the cases before it... The sufficiency of the evidence before it is a matter to be appraised by it alone and is not subject to review by the ECJ on appeal, except where that evidence has been distorted or the inaccuracy of the findings of the EGC is apparent from the documents in the case-file.' Case C-619/13 P Mamoli Robinetteria $v$ Commission, para 117.

${ }^{49}$ For instance, Case T-539/10 Acino v Commission, para 82. 
for which it has been severely criticised.$^{50}$ It relies on the written pieces of evidence provided by the parties. The most common explanation is a fear from relinquishing the judicial power to experts, whose credentials would be difficult to verify and compare, and allowing their battles in the courtroom. Independent fact-finding by the EGC would also increase the costs of proceedings. ${ }^{51}$

Like the EGC, the BoAs deal with appeals against individual administrative decisions lodged by these decisions' addressees. Interestingly, the legislative regulations setting up the examined BoAs have not been explicit on whether the BoAs are authorised or forbidden from raising new substantive pleas on their own motion if deemed necessary. ${ }^{52}$ Perhaps as a matter of path dependence, the authors of the BoA rules of procedure - the Commission, the agencies or the BoAs themselves - replicated in their procedural rules notions suggesting the system of pleas, ${ }^{53}$ such as those describing the necessary content of appeals. ${ }^{54}$

${ }^{50}$ Among many, Barbier de la Serre and Subony and Fritzsche (n. 5).

51 Ibid.

${ }^{52}$ For instance, Articles 92(2) and 93(2) REACH stipulates that the appeal will be lodged 'together with the statements of the grounds thereof' and 'the appeal will be remitted... for examination of the grounds...'. See also analogous provisions regarding ESAs BoA in Article 60(2) and (4) of the ESAs regulations (Regulation 1093/2010, OJ L 331/12; Regulation 1095/2010, OJ L 331/84; Regulation 1094/2010, OJ L 331/48); regarding the SRB Appeal Panel see, Article 85(3) and (7) of the Regulation 806/2014, OJ L 225/1; regarding the ACER BoA see, Article 28(2) and (4) of the Regulation 2019/942, OJ L 158/22 (with regard to these two BoAs the legislative provisions only require them to verify if the appeal is 'well-founded', arguably, without suggesting the restriction to the pleas raised by the appellant). At the same time, regarding the EASA BoA Article 110 and 112 of Regulation more clearly specifies the task of the BoA, by stipulating that 'where the Board of Appeal finds... that the grounds for appeal are founded..., it shall remit the case to the agency'. On the contrary, the legislative provisions governing the EUIPO BoAs explicitly authorises them to raise certain substantive pleas, which are considered to be of public interest, on their own motion. See, Article 27 of the Commission Delegated Regulation 2018/625, OJ L 104/1.

${ }^{53}$ By the same token, the ECHA BoA replicated the EU Courts' doctrine on the procedural pleas in law that are of public interest and may be raised by the BoA on its own motion. Case A-020-2013 Ullich Biodiesel v ECHA, paras 23-25.

${ }^{54}$ For instance, Articles 6 and 12(2) of the ECHA BoA rules of procedure (Commission Regulation No 771/2008, OJ L 206/8) specify that the notice of appeal must contain 'the pleas in law and the arguments of fact and law relied on' and that 'no new plea in law may be introduced after the first exchange of written pleadings...'; regarding the ESAs BoA see, Article 5(4) and Article 9(2) of its rules of procedure (adopted by itself, BoA 2020 01) which only specify that the question of the appeal admissibility may be raised on the BoA's own motion; regarding the SRB Appeal Panel see, Article 5(4) and 9(2) , 
Domestic traditions or previous experience of individual BoA members might have also played a role. ${ }^{55}$ As a matter of procedural practice, the examined BoAs have embraced systems of pleas modelled upon that of the court annulment proceedings.

The experience of the ECHA BoA moreover shows that the system of pleas is a convenient tool for moderating BoA's tasks in the face of limited resources. Whether the system of pleas was to apply to the ECHA BoA was far from clear in its early days. The REACH Regulation, ${ }^{56}$ as well as the ECHA BoA rules of procedure, drafted by the ECHA, were ambiguous on this fundamental feature of appeal proceedings and the BoA's essential role. ${ }^{57}$ In one of its first decisions, the ECHA BoA held that, as an administrative body, it should not confine itself to examining only the pleas raised by the appellant but examine the correctness of the impugned decision in its entirety. It mostly relied on a provision of REACH which allowed it to exercise any competence of the ECHA, including to modify the operative part of the contested decision and not only quash it. In this case, the ECHA BoA also obtained a relevant piece of evidence on its own motion; a task which admittedly was not very complicated since the relevant piece was a FAQ document previously available on the ECHA website. ${ }^{58}$

Nonetheless, in its subsequent practice, the ECHA BoA did not follow this approach and, instead, assumed a more limited role generally modelled on that of the EGC. At the same time, the ECHA BoA may tend to be more flexible than the EU Courts regarding its

which also specify that the Panel may raise the questions of admissibility on its own motion; regarding the EASA BoA see, Articles 17, 23(1), 25 and 33 of its rules of procedure (adopted by itself on 26.10.2017); regarding the ACER BoA see, Article 8, 16(1), 17(1-2), 21(1) and 24(1) of the ACER BoA rules of procedure (adopted by itself, Decision 1-2011).

${ }^{55}$ For instance, the Chairman of ESAs BoA admitted that the source of inspiration for the ESAs BoA rules of procedure where the procedural rules of international arbitration tribunals which, in turn, are inspired by Anglo-Saxon tradition of adversarial court proceedings. William Blair, 'Board of Appeal of the European Supervisory Authorities' (2013) 24 European Business Law Review 165-71.

${ }_{56}$ Regulation 1907/2006 of the Parliament and of the Council of 18.12.2006 concerning the Registration, Evaluation, Authorisation and Restriction of Chemicals (REACH), establishing a European Chemicals Agency, amending Directive 1999/45/EC and repealing Council Regulation (EEC) No 793/93 and Commission Regulation (EC) No 1488/94 as well as Council Directive 76/769/EEC and Commission Directives 91/155/EEC, 93/67/EEC, 93/105/EC and 2000/21/EC, O.J. 2006 L $396 / 1$.

57 See above n. 52 and 54.

${ }^{58}$ ECHA BoA, Case A-001-2010 N.V. Elektriciteits, paras 30-37. 
interactions with the appellants, who do not need to have a professional legal representation, ${ }^{59}$ when it comes to clarifying the contents of the appeals. ${ }^{60}$ Given the voluminous case files before the ECHA BoA and the fact that it is the smallest unit in the ECHA, it would be difficult to expect this BoA to perform broader review without significant structural changes. The ECHA BoA's rules for taking the evidence provide for the possibility to obtain relevant evidence on its own motion. In practice, however, this BoA relies on the written pieces of evidence (scientific studies) provided by the parties, and the appellant's activity is crucial for the outcome of the litigation. ${ }^{61}$ This partisan evidence does not have, however, the same probative value as independent studies that could hypothetically be commissioned by the BoA. ${ }^{62}$ The analysis of decisions of the other BoAs has neither allowed to identify instances of more pro-active fact-finding.

Nonetheless, such a system should not be taken as a 'natural' characteristic of judicial or administrative appeal proceedings at the EU level, ${ }^{63}$ or as the only conceivable procedural model thereof. The choice of a specific procedural model, in which adjudicators play a more passive or active role, is not value-neutral. Instead, it gives expression to a specific conception of the abstract balance and concrete implementation of process values. How many resources is the society ready to allocate the system of administrative justice to secure the individual rights of entrepreneurs against what may seem to appear as excessive protection of public interest goals. To what extent should the adjudicators, such as EU judges and BoA members, be made responsible for autonomously determining the most justifiable course of administrative action, in the name of protection of said individual rights, when they face significant empirical and normative uncertainty? Should their task be constrained to the benefit of first-instance decision-makers' discretion in order to avoid unnecessary spending, delays and protracted risk to the public interest at stake? After all, the appeals to the ECHA BoA, ${ }^{64}$ unlike the remaining examined BoAs, have a suspensory

\footnotetext{
${ }^{59}$ Article 9 of the ECHA BoA rules of procedure (n. 52).

${ }^{60}$ For instance, ECHA BoA, Case A-004-2014 Altair Chimica et al., paras 23-24.

${ }^{61}$ For instance, ECHA BoA, Case A-014-2014 BASF Pigment, para 38.

62 ECHA BoA, Case A-006-2017 Climax Molybdenum, paras 34-36.

${ }^{63}$ Note, for instance, that the ACER BoAs decided, with some opposition from the litigants, that the principles governing the EU judicial review should govern also the EU administrative review proceedings as they are of similar nature. ACER BoA, Case A-001-2019, Amprion \& Transnet, paras. 79.

${ }^{64}$ Like the appeals to the EUIPO and CPVO BoAs.
} 
effect, ${ }^{65}$ which potentially delays the provision of scientific data on substantial risks to public health and the environment.

Overall, the system of pleas - as practised by the EU judicature and the BoAs - determines the fundamental feature of judicial and extra-judicial review. Rather than independently establishing 'objective truth', these mechanisms require the applicants and appellants - to a considerable extent - to indicate, explain and eventually prove gaps in the empirical foundation of the aAdministrative action and related normative appraisals.

\section{Uncertainty on Trial Before the EU Courts}

\subsection{Keeping Science at Arm's Length}

The EU Courts and the BoAs engage differently with different kinds of pleas in law. A plea may relate to the competence to adopt the contested measure, essential requirements of the adoption process, substantive legal norms determining the content of the measure, or abuse of law. ${ }^{66}$ At the same time, a plea may be geared towards either an allegedly incorrect interpretation of the law or an allegedly incorrect legal evaluation or qualification of relevant facts. ${ }^{67}$ The EU Courts and the BoAs assert the power to fully reconsider the legal interpretation of relevant provisions favoured by the primary decision-makers. However, they may struggle with the allegedly incomplete or inaccurate factual determinations and assessments in light of the applicable legal norms.

When legal norms, such as those defining the conditions in which EU bodies may exercise their authority, use indeterminate concepts, it is a matter of reasoned arguments as to whether, for instance, a given chemical substance poses 'a serious risk to public health'. In that case, the review bodies may be inclined to defer to a discretionary assessment by the first-instance decision-makers as to whether, for instance, the evidence gathered by the administration is sufficient to identify a risk to public health. The primary decision-makers are usually equipped with more significant organisational resources, access to expertise or

\footnotetext{
${ }^{65}$ Article 91(2) of the REACH Regulation (n. 56).

${ }^{66}$ The latter's origin lies in French law and relates to the use of a competence to achieve a different purpose than that for which the competence has been conferred. See, Article 263(2) TFEU.

${ }^{67}$ Prek and Lefèvre (n. 10), 348.
} 
other legitimacy assets (such as a broader and more representative composition of decisionmaking committees or political accountability). When the evidence leads to divergent or uncertain conclusions, the legitimacy assets of decision-makers come to the fore. ${ }^{68}$

The process-oriented technique is intended to warrant meaningful judicial review, saving judges the task of amateur scientists, engineers or economists. Initially, the EU Courts have recognised a 'wide measure of discretion' ${ }^{69}$ of EU institutions and bodies - sometimes referred to as a 'margin of discretion'70 - with regard to decision-making involving a collection, interpretation and balancing of technical or scientific factors. Carrying out such a complicated process may require a degree of specialist knowledge unavailable to most lawyers. When such discretion is warranted, the EU Courts verify - as they declare whether the administration has accurately stated and assessed the relevant empirical factors. They reach for procedural safeguards such as 'a scientific risk assessment carried out as thoroughly as possible on the basis of scientific advice founded on the principles of excellence, transparency and independence'. On the contrary, 'it is not for the General Court to substitute its assessment of complex facts for that of the institution which adopted the measure' ${ }^{71}$ A similar formula applies to the review of discretionary measures based on constitutional standards or proportionality. ${ }^{72}$ The EU Courts may identify a manifest error of assessment, if 'the evidence adduced by the applicant [is] sufficient to make the factual assessments used in that measure implausible' ${ }^{73}$

The latter formula emphasises the paramount role of the applicant's active participation in the judicial review proceedings. The applicant is effectively shouldered with the burden of

\footnotetext{
${ }^{68} \mathrm{~A}$ good example is the comparison between the institutional assets of the ECHA BoA (composed of three members and supported by a small unit) and the ECHA Member State Committee (its main decision-making body) composed of experts delegated by national authorities and supported by resourceful domestic chemical regulators. See, Lucas Bergkamp, The European Union REACH Regulation for Chemicals: Law and Practice (OUP 2013), 29.

${ }^{69}$ Case C-55/75 Balkan Import \& Hauptzollamt Berlin-Packhof, para 8. More recently, Case Case T-446/10 Dow AgroScience et al. $v$ Commission, para 64 .

${ }^{70}$ Case C-12/09 P Commission v Tetra Laval, para 39. See also, Case T-13/99 Pfizer Animal Health v Council.

${ }^{71}$ Case T-584/13 BASF $v$ Commission, paras 92-96 and the previous case law cited therein.

72 Case T-96/10 Rütgers Germany v ECHA paras 133-134.

${ }^{73}$ Case T-584/13 BASF v Commission, para 94
} 
providing the evidence and elucidating its meaning to the judges. ${ }^{74}$ The level of the applicant's initiative and resources determines the EU Courts' ability to verify whether the challenged administration has examined 'carefully and impartially all the relevant elements of the individual case ${ }^{\prime 75}$ beyond the review of the superficial appearance of coherence and comprehensiveness of the statement of reasons. If the applicants provide only general arguments against the scientific or technical findings underpinning EU administration's decisions, expecting the EU judicature to independently confirm or refute these findings using its own procedural tools and resources, they may be quite disappointed. ${ }^{76}$

In the part of the examined cases of the EU Courts (definitively closed in 2014-2018), relating to public health or the environment, the applicants raised a variety of pleas regarding allegedly inaccurate empirical determinations and assessments, or the normative adequacy or proportionality of the impugned measures. ${ }^{77}$ These cases specifically concerned, for instance, a restriction on the use of a pharmaceutical substance despite a difference of opinion within an expert committee on its safety and benefits, or whether a bio-informatic analysis had sufficiently demonstrated a link between a food supplement and antibiotic resistance of some bacteria. Such cases usually concern measures taken by the EU administration in the name of public interest while acting to the detriment of specific economic operators. In these cases, importantly, the EGC was often called directly to delve into the details of scientific data to decide what kind of conclusions could be legitimately drawn from them.

\footnotetext{
${ }^{74}$ The EU judges do not even have ex officio access to the documents produced by the EU bodies relevant to the case at hand. See Case T-100/15 Dextro Energy v Commission, paras 42-43. Sometimes, the applicants may resort to different kinds of auxiliary materials during the oral hearings (like printed schemes, illustrations) which could help them elucidate their complex point. See, for instance, AG Mengozzi, Case C-680/16 P Dr. August Wolff v Commission, para 163.

${ }^{75}$ Case C-269/90 Technische Universität München, para 14; recently Case T-584/13 BASF v Commission, para 95.

${ }^{76}$ For instance, Case T-115/15 Deza v ECHA, paras 186, 192-195 and 199.

77 The specific criteria for the selection of cases have been discussed above (n. 21 and 22).
} 
Were the legal generalists at the EGC able to verify the actual weight of scientific arguments and counter-arguments, ${ }^{78}$ their relevance to the case at hand, ${ }^{79}$ the quality of data ${ }^{80}$ or the causal links between the product and a risk to public health ${ }^{81}$ One needs to maintain caution while evaluating the reasoning of the EU Courts, as well as other review bodies, without having specialist expertise or at least in-depth knowledge of the facts and context of each case. However, the reasoning provided in some cases may lead a reader to certain doubts regarding the thoroughness of review. The reasoning presented in some cases makes an impression that the EGC was actively looking for a way to uphold the contested decision, despite weak evidence, due to potentially high risks to public health or the environment. ${ }^{82}$ Dealing with pleas relating to a failure to take into account some data favourable to the applicant, the EGC might confine itself to verify whether this data had been somehow referred to in the administrative process or the scientific opinion, without a more in-depth

${ }^{78}$ For instance, in Case T-368/11 Polyelectrolyte Producers Group et al. $v$ Commission, para 34, the EGC has confined itself to checking whether the counterarguments contained in the consultancy report were simply mentioned in the impact assessment report.

${ }^{79}$ For instance, are the studies undertaken in the US relevant to assessing the situation in Europe, given that the substance in question was used by the industry in a different manner? ibid., para 48. Should an imperfect method of manufacturing a substance, which resulted in cancerogenic impurities, but which was not used in the EU, be taken into account while assessing the safety of the substance in the name of the precautionary principle? Case T-400/17 Deza v Commission, paras 27-39. Are 'generally accepted nutrition and health principles', such as the need to avoid nowadays the consumption of sugars, relevant to assessing the health claims that the producers wish to display on their products, even though the applicable legislation has been ambiguous on this issue? Case T-100/15 Dextro Energy, paras 31-34.

${ }^{80}$ For instance, see the EGC's analysis of the 'realistic and forseeable' conditions of 'correct usage' of the product in question, Case T-368/11 Polyelectrolyte Producers Group et al. v Commission, paras 55-62.

${ }^{81}$ For instance, in Case T-400/17 Deza v Commission, paras 46-49, a competent scientific committee admitted that it was impossible to state whether carcinogenicity is caused by the substance in question itself or only its impurities that result from methods of production not relevant to the EU market. However, the committee 'found it unlikely that the carcinogenic activity were to be attributed solely to the impurity...' given a low presence of this impurity in the tested sample. As uncertain assessment as it is, the EGC did not find it appropriate to quash it, invoking the principle of limited review in scientifically complex cases.

${ }^{82}$ For instance, above n. 78-81. 
examination of why precisely it had been deemed 'not sufficiently robust' or not to address the matter 'in a satisfactory manner' ${ }^{83}$

On the one hand, it is entirely possible that the applicants oppose the EU institutions and bodies using weak arguments and evidence. On the other hand, the summarily way in which the EGC tend to dismiss certain empirical assertions leads to doubts, without examining the full administrative and scientific case-file. At times, it was unclear for a reader whether the EGC had taken for granted the arguments of the administration or, rather, it confirmed that these were good arguments, at least considering the weaknesses of the applicant's counter-arguments. In other words, the procedural context of the system of pleas hinders an unequivocal assessment of the thoroughness of judicial review. A reader of judicial decisions must always keep in mind that the EGC depends on the arguments and specialist expertise provided by the two opposing parties. ${ }^{84}$ The fact that the applicant has not managed to provide convincing counter-arguments and counter-evidence does not necessarily mean that the administration's empirical assertions are objectively correct. Putting these assertions in question, effectively, may require resources above those at the disposal of the applicants.

Similar doubts relate to how the EU Courts assess the proportionality or adequacy of impugned measures. The EU judicature has no independent instruments to verify, for instance, whether a specific restriction upon the use of a substance is suitable in specific circumstances, given that alternatives to this substance may pose a higher risk. ${ }^{85}$ The EU judicature may have difficulty figuring out a possibly less onerous measure. ${ }^{86}$ Deference or merely checking whether the EU administration has somehow explained its choice in the statement of reasons, a prior impact assessment or in the course of the administrative process may be the only available solution. ${ }^{87}$

\footnotetext{
${ }^{83}$ For instance, Case T-269/11 Xeda International v Commission, para 84. See also, para 69.

${ }^{84}$ For instance, Case T-135/13 Hitachi et al. $v$ ECHA, paras 59-60 and 76.

${ }^{85}$ Case T-368/11 Polyelectrolyte Producers Group et al. $v$ Commission, para 81.

${ }^{86}$ If the applicant challenged the measure based on the second prong of proportionality, she should indicate a less onerous measure capable of fulfilling the pursued objective. For instance, Case T-269/11 Xeda International v Commission, para 146.

${ }^{87} \mathrm{Ibid}$., paras 85-97. Still, the EU judicature may be able to declare the contested measure unlawful in an extreme scenario in which the Commission has not carried out or is unable to prove any prior impact assessment, Case T-584/13 BASF $v$ Commission, paras 157-173.
} 
The crucial point of contention in the examined cases was often the findings of independent scientific committees or agencies, underpinning the contested measures. The judicial review was openly less thorough concerning these opinions, even though they might have effectively determined the substance of the contested measures. The EU judicature emphasised that such committees are independent from the Commission and composed of experts, so it was reluctant to delve into their reasoning. ${ }^{88}$ Instead, it verified whether the reasoning presented to back up the findings was intelligible and logical. This practice could guarantee some degree of meaningful review. For instance, when conflicting evidence was available, a committee was obliged to justify its choice of relevant evidence ${ }^{89}$ In a recent case, however, of several pleas relating to potential errors of assessment by a scientific committee the ECJ chose one regarding the procedural requirement of the committee rapporteur's impartiality and quashed the EGC ruling on this ground. At the same time, it set quite a high procedural standard of impartiality for such committees..$^{90}$

It was entirely up to the applicant, however, to explain and prove why a committee's opinion is unreliable. ${ }^{91}$ The EGC trusted reasons provided by the challenged institution as to the opinion's validity, such as a variety of available scientific studies, meta-analyses, compliance with methodological standards and good practices (control groups, randomising), an agreement between different experts, or the fact that the expert body had already responded to the applicant's scientific arguments..$^{92}$ Notably, the Commission is generally allowed to depart from the committee's opinion if it can provide grounds for doing so. However, that the Commission had followed the committee's opinion or the view of national expert bodies was used by the EU Courts as an argument supporting the

${ }^{88}$ T-189/13 PP Nature-Balance Lizenz v Commission, paras. 33-34 and the previous case law cited therein.

${ }^{89} \mathrm{Ibid} .$, paras 52 and $59-62$.

${ }^{90}$ While in Case T-672/14 August Wolff and Remedia $v$ Commission, the EGC tried to engage with complex substantive pleas regarding the lawfulness of a pharmaceutical authorisation which did not lead to a detection of error, on appeal, in Case C-680/16 P, August Wolff and Remedia v Commission, the ECJ disregarded procedural pleas and decided, instead, that the procedural standards - notably, those relating to impartiality - enforced upon the scientific committee which examined the case should be stricter. The problem was that the same person had worked for the national authority which demanded a non-renewal of the authorisation for the pharmaceutical product in question and, later, had also been the main rapporteur for this case within the competent EU committee.

${ }^{91}$ For instance, Case T-400/17 Deza $v$ Commission, paras 46-54 and 57.

${ }^{92}$ For instance, Case T-539/10 Acino v Commission, paras 95-98, 101-103. 
contested measure. ${ }^{93}$ At times, the EGC sought to deal with allegations against scientific opinions by highlighting crucial aspects of scientific studies that the applicant had not contested, $^{94}$ or pinpointed inconsistencies and self-contradictions in the applicant's reasoning. ${ }^{95}$

The EGC judges appear able to detect the most blatant methodological flaws of scientific studies and autonomously assess their evidential value, ${ }^{96}$ but their ability to scrutinise more intricate methodological problems may raise doubts. ${ }^{97}$ For instance, EU administration is often authorised to take a preventive measure to moderate a newly discovered risk of a chemical or pharmaceutical substance. Data on such risk are rarely unambiguous. Their interpretation may imply a political choice regarding the level of risk acceptable to the society. Disentangling the empirical from the political assessment may raise practical difficulties for the judges. At the same time, with overly 'cautious' administration and too deferential courts, the affected economic operators, rather than demonstrating the insufficiency of the evidence as to the existence of risk, would have to prove the absence of

${ }^{93}$ Case T-189/13 PP Nature-Balance Lizenz v Commission, paras 45-49; Case T-96/10 Rütgers Germany and Others v ECHA, para 129; Case T-539/10 Acino v Commission, paras 80-81; Case T-368/11 Polyelectrolyte Producers Group and Others v Commission, para 48.

${ }^{94}$ Case T-201/13 Rubinum v Commission, para 65; Case T-135/13 Hitachi Chemical Europe and Others v ECHA, paras 58-60.

${ }_{95}$ For instance, Case T-135/13 Hitachi Chemical Europe and Others v ECHA, paras 67, 77 and 115-116. However, in Joined Cases T-339/16, T-352/16 and T-391/16 Ville de Paris $v$ Commission, paras 129, 136 and 142-143, where the EGC, in short, criticised the Commission for maintaining that it must have introduced very significant 'coefficients' to account for the 'overestimation' of car pollution while measured in use as compared to that measured in a laboratory - which might actually lead to surpassing the pollution limits as set by the co-legislators - even though the Commission had itself admitted that the method for measuring the pollution while the car is in use had been significantly developed over the previous years, so it should have already been possible to narrow down the coefficients to stay more in line with the limits set by the co-legislators.

${ }_{96}$ Case T-135/13 Hitachi Chemical Europe and Others v ECHA, para 74. See also, Case T-446/10 Dow AgroScience et al. $v$ Commission, paras 40-42, in which the EGC was able to compare the conclusions drawn from the relevant data for the purpose of somewhat difference procedures.

${ }_{97}$ For instance, Case T-400/17 Deza v Commission, paras 70-88, regarding whether new scientific findings regarding the susceptibility of particular species to cancer, especially when the animals are fed with the substance in question using a particular method, should cast doubt on the viability of the study regarding the substance's carcinogenicity. 
risk whatsoever or the perfect safety of their products, which for practical reasons may turn out impossible. ${ }^{98}$

\subsection{Judges Learning Economics... and Avionics?}

Similar doubts pertain to other policy areas too. The process of intensifying the EU judicial review technique was inspired mainly by expectations of competition lawyers and scholars who expected the EU Courts to be capable of delving into the economic analyses underpinning the Commission decisions. The EU judicial review in competition matters is nowadays considered comprehensive by many..${ }^{99}$ Over the years, the members and staff of the EU judicature have had time to acquire a certain degree of relevant expertise. Most recently, they have been called upon scrutinising the ECB's decisions regarding banking supervision. It has been argued that, despite the novelty of these economic issues, we are likely to observe with time a gradual alignment of the review technique applied in banking supervision and competition matters. ${ }^{100}$

For now, the EGC has repeated the standard formulas foretelling the process-oriented review. In the first series of cases regarding the judicial review of ECB's supervisory role, the EU Courts did not shy away from directly engaging with the ECB's assessment. ${ }^{101}$ The case concerned the 'leverage ratio', a prudential regulatory tool, calculated as a credit institution's capital divided by the institution's total exposure. The ECB may authorise a credit institution to exclude specific exposures to public bodies from its ration calculation,

\footnotetext{
${ }^{98}$ For instance, Case T-584/13 BASF Agro and Others v Commission, paras 137-144. For instance, in Case T-201/13 Rubinum v Commission, paras 73-75, the applicant claimed that a potential detection of a gene usually associated with chloramphenicol in a specie of bacteria used by the applicant and in other related species is not a sufficient proof that the product may provoke a resistance to antibiotics, especially that even the European Food and Safety Authority used a phrase 'strongly suggests' rather than 'proves'. See also, T-96/10 Rütgers Germany and Others v ECHA, paras 128-129.

${ }^{99}$ Fernando Castillo de la Torre and Eric Gippini Fournier, Evidence, Proof and Judicial Review in EU Competition Law (Edward Elgar 2017), 285-86.

100 Andrea Magliari, 'Intensity of Judicial Review of the European Central Bank's Supervisory Decisions' (2019) 17 Central European Public Administration Review 73-86.

${ }^{101}$ Case T-768/16 BNP Paribas v ECB. Case T-758/16 Crédit agricole v ECB. Case T-757/16 Société générale v ECB. Case T-751/16 Confédération nationale du Crédit mutuel v ECB. Case T-745/16 BPCE v ECB. Case T-733/16 Banque postale v ECB.
} 
but it refused to do that in the case of several French banks. These banks had sought to have their exposures connected to saving accounts excluded as the French law required some of these deposits to be transferred to a public financial institution.

The EGC confirmed that the ECB had had discretion to consider both financial stability and the realistic representation of risks in which financial institutions were involved. However, the EGC found that the ECB made a manifest error of assessment because all the reasons by which its justified its discretionary decision have been, by their nature, inherent in the derogation provided for in the applicable regulation. ${ }^{102}$ The commentators took the judgment as a sign of the EGC's readiness to perform a searching review of the ECB's assessments. However, it could also be argued that the error of assessment identified in this case was particularly manifest as, in a way, the ECB had second-guessed the assessment of the law-makers, depriving the exception in the question of any practical effect.

In another recent case involving aviation safety technological considerations, the EGC was visibly more deferential. ${ }^{103}$ The key issue was the correct application of a concept of 'safe flight', which the applicant's aircraft was supposed to be capable of, in light of more concrete specifications contained in an annexe to the basic regulation. However, the EGC did not effectively have to delve into any abstruse technological considerations since the applicant's based its contentions on an incorrect claim that the burden of proving the ability of safe flight had rested on the EASA rather than the applicant. In fact, the applicant had not provided any specific evidence except for a certificate by a foreign authority. The EGC considered that the EASA was not under a duty to undertake additional inspections. ${ }^{104}$

\footnotetext{
102 These reasons were the fact that the exposure in question appeared as an asset in the institution's balance sheet, that the institution bore the operational risk linked to the regulated savings and that any default by the State would prevent the transferred savings to be returned to the customers. At the same time, the ECB had not provided any detailed analysis of the probability regarding the State's default.

${ }^{103}$ Case T-102/13 Heli-Flight GmbH \& Co. KG v EASA.

${ }^{104}$ Ibid., paras 85-86 and 91.
} 


\section{The Boards of Appeal: Review or Second-Guessing?}

\subsection{The Limits of the Legalisation of Science}

The EGC and the BoAs' review techniques cannot be compared straightforwardly due to differences in their jurisdiction and the nature of acts they deal with. The EU Courts directly review the legal acts of institutions and only indirectly the underlying scientific opinions of expert committees or agencies. On the contrary, the BoAs more closely confront the decisions of agencies incorporating empirical appraisals. Even from the purely formal point of view, therefore, the EU Courts may operate 'further' from the scientific and technical assessments than the BoAs.

The ECHA BoA regularly deals with a docket of cases which are not equally complex. In the most complex compliance check and substance evaluation cases, the ECHA verifies whether the data provided by the registrant are sufficient in terms of quality and comprehensiveness to demonstrate the safety of their products in light of requirements specified in the Annexes to the REACH Regulation ${ }^{105}$ or, otherwise, which new data and scientific tests are necessary to clarify doubts. Having identified an issue of concern, the ECHA may impose on the registrant costly testing duties.

Even in such complex cases, light-touch review occasionally turned out sufficient. The BoA's task consisted in clarifying the meaning of the contested decision during the appeal proceedings, ${ }^{106}$ sorting out potential inconsistencies and contradictions, ${ }^{107}$ and somewhat mediating between the parties. ${ }^{108}$ It also sought to narrow down the scope of the dispute, by

105 Regulation 1907/2006 of the European Parliament and of the Council of 18.12.2006 concerning the Registration, Evaluation, Authorisation and Restriction of Chemicals (REACH), establishing a European Chemicals Agency (...), OJ L $396 / 1$.

106 ECHA BoA, Case A-008-2017 SI Group UK and Osiris Chemicals, paras 86-96.

107 Ibid., paras 95; Case A-004-2015 Polynt, para 135; Case A-018-2014 BASF Grenzach, para 92.

${ }_{108}$ On several occasions, the appeal proceedings before the ECHA BoA helped interpret the requirements of the contested decisions that the appellants intended to clarify before taking the requested scientific tests. See, ECHA BoA, Case A-0082017 SI Group UK and Oxiris Chemicals, paras 86-96 and 108. 
detecting inconsistencies and self-contradictions in the appellants' reasoning, ${ }^{109}$ or drawing conclusions from the data which the applicant has not contested. ${ }^{110}$

For 'hard' cases, the BoA transplanted the EU Courts' formulas characterising processoriented review, i.e. the verification of the accuracy, reliability, consistency and comprehensiveness of relevant evidence, which should be capable of substantiating the conclusions drawn from it. ${ }^{111}$ Such abstract formulas perhaps make a purely semantic difference. ${ }^{112}$ In general, courts and similar bodies may style their reasoning in a specific way to achieve strategic goals and to legitimise themselves. In particular, the decisive importance should not be assigned to the rhetoric employed by the ECHA BoA who portrays its review as oriented towards identifying ordinary 'errors of assessments' (rather than 'manifest errors of assessments'). A rose by any other name would smell as sweet.

However, the review technique by the ECHA BoA appeared more thorough than that of the EU Courts inasmuch as the BoA scrabbled around in the detailed design of scientific tests or methodological issues surrounding the conclusions drawn from available chemical literature and studies. In similar cases, the EGC rather contented itself with the intelligibility and apparent completeness of the defendant's reasoning. The ECHA BoA formed an independent view on the persuasiveness of ECHA's scientific arguments and the quality of submitted studies, ${ }^{113}$ the importance of data gaps to be filled by the registrants, ${ }^{114}$ or the

\footnotetext{
${ }^{109}$ For instance, ECHA BoA, Case A-006-2016 SI Group UK et al., para 167ff and 177-178.

110 Case T-446/10 Dow AgroScience et al. v Commission, para 67.

${ }^{111}$ ECHA BoA, Case A-005-2011 Honeywell, para 76ff, referring to ECJ case law; Case A-006-2017 Climax Molybdenum, para 38.
}

112 Castillo de la Torre and Gippini Fournier (n. 99), 268 and 284.

${ }^{113}$ For instance, ECHA BoA, Case A-015-2015 Evonik Degussa et al., para. 161-169 and 175-186; Case A-009-2014 Albemarle Europe, paras 100-102.

${ }^{114}$ For instance, in ECHA BoA, Case A-006-2017 Climax Molybdenum, paras 54-77, the ECHA BoA came to the conclusion that the submitted studies were inadequate due to the difference in exposure duration, uncertainty as to the actual dose intake of the tested animals, the lack of appropriate coordination with the tested animals' mating periods, the inadequate dose levels as compared to the OECD guidelines and previous tests. In Case A-005-2016 Cheminova, paras 95-97, the ECHA BoA came to the conclusion that the proposed, so-called, read-across adaptation (a prediction of the properties of a substance based on a comparison with a different, similar substance) was not sufficiently justified as the appellant's justification relied on yet another predictive rather than evidence-based tool. 
reliability of inferences from existing data presented by the appellants. ${ }^{115}$ It also explained in a rather detailed way why the imposed testing obligation (chemical test) were considered by itself adequate to clarify the point of concern ${ }^{116}$ and whether they were ${ }^{117}$ or not disproportionately onerous. ${ }^{118}$ In these cases, the BoA did not suggest deference to the firstinstance decision-makers, although it made occasional comments regarding the insufficiency of the applicant's arguments or evidence to support its conclusion. ${ }^{119}$

The degree of uncertainty due to the lack of well-established and commonly agreed scientific methodologies might, however, led the BoA to exceptionally defer to the ECHA's assessments. ${ }^{120}$ As the ECHA BoA noted, 'the data available for substance evaluations is in

${ }^{115}$ ECHA BoA, Case A-004-2015 Polynt, paras 129-138.

${ }^{116}$ For instance, ECHA BoA, Case A-018-2014 BASF Grenzach, paras 42-45; Case A-013-2014 BASF SE, para 159-162.

${ }^{117}$ For instance, in ECHA BoA, Case A-008-2017 SI Group UK and Osiris Chemicals, paras 126-129, the BoA quashed the test imposed by the ECHA because the latter set out, in a disproportionate manner, as much as three separate specifications (the test at two different temperatures, the duration of at least six months, the assessment of transformation products formed at level of 1 or even $0.1 \%$ ) aimed at the increase of transformation products being identifiable at the end of the study. In Case A-026-2015 Envigo Consulting and DJChem Chemicals Poland, paras 122-125, the BoA rejected the ECHA's argument that the appellant should at least try to identify the metabolites of the investigated substance formed in the study, although the ECHA admitted that the test might actually not succeed in light of the specific properties of the substance (low solubility). The ECHA was not able to identify a suitable analysis method with a low detection limit so, in the BoA's view, it effectively shifted onto the appellant the onus for designing an adequate test. The ECHA was driven by the goal of obtaining data on the safety of the substance's transformation products but, in the BoA's view, could not for this reason burden the registrant with carrying out an expensive scientific test having low chances of success. See also, similar considerations in paras. 136-140.

${ }^{118}$ For instance, in ECHA BoA, Case A-006-2017 Climax Molybdenum, para 140, the ECHA BoA specifically suggested how the applicant might comply with the ECHA decision and design the tests to avoid unnecessary costs; in ECHA BoA, Case A-018-2014 BASF Grenzach, para 94, the BoA agreed with the ECHA that it was necessary to request persistence testing in both fresh and marine water compartments at the same time, because this testing takes considerable amount of time and it could not be predicted in which type of water the investigated substance was more likely to be persistent.

${ }^{119}$ For instance, ECHA BoA, Case A-013-2014 BASF SE, para 160.

${ }^{120}$ For instance, in ECHA BoA, Case A-023-2015 Akzo Novel Chemicals et al., paras 67-68 and 74-75, the parties used different calculation methods to assess the change of maternal body weight after the exposure to the investigated substance and, thus, the severity of its maternal toxicity. The applicable legal provisions did not include a method for this calculation and how to categorise the results as a slight, moderate or severe toxicity. If the maternal toxicity had been deemed slight, the 
some cases inconsistent or indeed contradictory and in other leave questions open. It is therefore not surprising that there is often a difference of opinion between experts when assessing the available data'. ${ }^{121}$ In such cases, the ECHA BoA could only make sure that the arguments of the appellant have been appropriately considered and addressed in the course of first-instance decision making. ${ }^{122}$

A more detailed comparison of the EU Courts and the ECHA BoA's review technique would require an in-depth engagement with individual cases. In particular, the meaning of judicial or extra-judicial review as an institutional practice manifests itself also in the course of proceedings, for instance, during the face-to-face deliberation between the parties and adjudicators at oral hearings. After completing the procedure, the adjudicators are at liberty to choose how much of their actual reasoning they disclose and how they style it.

It seems that if the ECHA BoA were to exercise even more searching review in the most complex cases, in which it has hitherto demonstrated deference, it would have to either second-guess scientific opinions - which in and of itself could face allegations of arbitrariness - or repeat parts of the first-instance proceedings. In the latter case, it would need a much more robust institutional structure and organisational resources. A broader composition reflecting the variety of ECHA's stakeholders might deliver more vital legitimacy assets. In the ECHA BoA decision-making, empirical considerations are inextricably linked to normative value judgments. Underlying decisions regarding the sufficiency of the evidence (in the face of empirical uncertainty) or the adequacy and proportionality of the imposed testing obligations (in the face of empirical and normative

ECHA could have concluded that there is a separate issue of developmental toxicity (i.e. to foetuses) to investigate, not merely secondary to maternal toxicity. Since the numbers of 5,3-5,5\% presented by the parties were well beyond $20 \%$ - a number indicated as problematic in a study on which the appellants themselves based much of their arguments - the BoA ultimately concluded that the ECHA had not committed an error in stating only a slight maternal toxicity and, hence, a distinct concern about developmental toxicity. The BoA added in para 76 that provisions of the 'Annex I to the CLP Regulation acknowledge that the assessment of whether the development of offspring... can be influenced by toxic effects in the mother is a complex issue because of uncertainties surrounding the relationship between maternal toxicity and developmental toxicity.'

${ }^{121}$ ECHA BoA, Case A-015-2015 Evonik Degussa et al., para 174. See also, Case A-018-2014 BASF Grenzach, para 134 and 155156.

${ }^{122}$ For instance, ECHA BoA, Case A-015-2015 Evonik Degussa et al., paras 170-174; Case A-018-2014 BASF Grenzach, paras 57-64, 163-165. 
uncertainty) are discretionary choices between competing values. ${ }^{123}$ The empirical findings underpinning regulatory decisions should undoubtedly be as methodologically exact and faultless as possible. Nevertheless, what conclusion can reasonably be inferred from the data, although inter-subjectively verifiable through argumentation, is in no small extent 'political'. ${ }^{124}$

\subsection{Reviewing Expert 'Gut Feeling'}

Two appeal bodies currently scrutinise agency action in the field of financial supervision and resolution: the Joint BoA of ESAs and the SRB Appeal Panel. Their output is still less robust than the output of the ECHA BoA, but some conclusions can be drawn from it. Besides several cases raising issues of jurisdiction and admissibility, the ESAs BoA has dealt with only a few cases relating to the contentious legal evaluation of empirical data.

Two cases concerned the decisions of the European Securities and Markets Authority (ESMA) to reject applications to register sovereign credit rating agencies due to the failure to provide sufficiently detailed information on the applicant's internal arrangements and methodologies. Following a detailed analysis of applicable legislation and the information provided by the applicants, the BoA confirmed the ESMA's assessment. Although the processing of empirical data, in this case, did not arguably require extensive specialist knowledge, what was interesting was how the ESAs BoA presented its reasoning. It

\footnotetext{
${ }^{123}$ For instance, in ECHA BoA, Case A-015-2015 Evonik Degussa et al., paras. 144-159, the ECHA presented evidence showing that only one type of the investigated substance had potential inhalation toxicity. The ECHA also contended that the unexplained differences in toxicity between different types of this substance, many of which were marketed by the appellants, was in itself a potential concern to clarify. Importantly, the appellants themselves had described the marketed substance in their registration dossier in broad terms, encompassing its multiple types, but had not provided data explaining the toxicological differences between the different types. The ECHA's approach was therefore much more precautionary in that it requested data on many different types of the substance. The BoA approach was ultimately more evidence-based in that it held that the ECHA's decision was not supported by any evidence specifically relating to the other types of the substance. Moreover, the ECHA did not explain specifically how it would use the considerable amount of requested data on physiochemical properties of the substance to clarify the identified potential concern.

${ }^{124}$ See, ECHA BoA, Case A-004-2014 Altair Chimica et al., para 96.
} 
employed a somewhat personal style, featuring an independent opinion rather than an entirely disinterested detection of manifest or objective errors. ${ }^{125}$

This drafting style may convey the impression that the BoA has performed a fully autonomous legal evaluation of facts. In other words, it may express the BoA's selfunderstanding of the scope of its mandate, greater than that of the EU Courts, although it may also stem from the BoA members professional or cultural background. ${ }^{126}$ The BoA members, in their non-official statements, expressed readiness to engage with more intricate economic problems, but at the same time, they highlighted the need for more training, support and resources. ${ }^{127}$

Another aspect of these decisions confirms, nonetheless, the inextricable connection between the parties' activity in the adversarial model of review proceedings and the achievable thoroughness of review. As regards an unclear issue on whether the rating methodology proposed by the appellant was sufficiently detailed, the BoA held that 'the decision of the respondent acting as a specialist regulator is entitled to some margin of appreciation... On balance, the Board is reluctant to interfere with the respondent's conclusion in this regard.' ${ }^{128}$ The direct reason why the BoA invoked the 'margin of appreciation' might have been less the intricacy of the problem but rather the low quality of

${ }^{125}$ Take 'the Board's accepts the appellant's point... however, the Board agrees that the respondent is correct to point out...' (ESAs BoA, Case BoA 201701 Financial Craft Analytics v ESMA, para 70-71, see also for instance paras 75-76, 80-81, 85-86, 91); 'although the position is less than clear, the Board prefers the appellant's contention in this regard...', or 'the Board does not agree with this approach...' (ESAs BoA, Case BoA 2013-14 Global Standard Rating v ESMA, paras 137 and 111, see also for instance paras 101-102, 112); 'there is nothing in the material that the Board of Appeal has seen to suggest that...' (ESAs BoA, Joined Cases BoA-D-2019-1 to 4 Svenska Handelsbanken et al. $v$ ESMA, para 207); 'in the Board of Appeal's view, this was a sensible approach...' (ibid., para 225).

${ }^{126}$ As already mentioned, the BoA Chairman declared being inspired by international commercial arbitration, which is itself inspired by common law systems. Blair (n. 55).

${ }^{127}$ Marco Lamandini and David Ramos Munoz, 'Law and practice of financial appeal bodies (ESAs' Board of Appeal, SRB Appeal Panel): A view from the inside' (2019) 57 Common Market Law Review 119-60.

${ }^{128}$ ESAs BoA, Case BoA 201701 Financial Craft Analytics v ESMA, para 87. 
both parties' arguments. The BoA explicitly considered these arguments deficient, so it might have had no choice but to apply deference. ${ }^{129}$

Another case before the ESAs BoA raised the question of whether Nordic banks have negligently disregarded the regulation on credit ratings by carrying on their practice of publishing, without registration, what they perceived as merely 'research reports'. In that case, the BoA 'respectfully differ[ed] with the Board of Supervisors in its assessment (...) of whether the appellant banks acted negligently...' ${ }^{130}$ It disagreed with the ESMA by noting that the contentious practice was long prevalent in the Nordic market, without any questioning from domestic authorities. The impact of the new EU regulation was, in the BoA's view, not sufficiently foreseeable to state a 'negligent' disregard of EU law. ${ }^{131}$ The issue of whether the appellants had acted 'negligently' was highly discretionary, in more 'political' than technical sens, which would suggest again that the ESAs BoA considers it appropriate to substitute the first-instance discretionary assessments with its own. At the same time, that case may be considered quite specific as relating to administrative sanctions, the review of which may require 'full review' under fundamental rights standards.

The SRB Appeal Panel also applied deferential review. ${ }^{132}$ Empirical uncertainty characterised a case regarding the application of MREL rules, which ensure that a bank has sufficient resources for the event of a resolution. The Appeal Panel held that in the calibration of MREL requirements the [Single Resolution] Board enjoys a margin of technical discretion because the MREL calibration implies, by its very nature, a technical assessment of all specific factual circumstances and a balancing of interests and that it is not the Appeal Panel's role to second-guess the Board's technical assessment.' Since the MREL determination may have far-reaching consequences for the bank's profit and

129 'It does not accept the assertions of the appellant... But the respondent's Response is not particularly cogent in explaining precisely how... despite what the Board regards as an under-developed Response...', ibid., paras 86-87.

${ }^{130}$ Ibid., para 321.

131 Ibid., para 304.

132 The SRB Appeal Panel has issued several decisions in which empirically unertain appraisals were not involved, regarding the calculation of contributions to the SRB expenses and access to documents. In the former, the crux of dispute was the correct interpretation of specific legal provisions. In the latter, the Appeal Panel had to decide important matters of principle such as the transparency of the resolution process and its impact on the access to judicial review and the protection of fundamental rights. Lamandini and Ramos Munoz (above n 127). 
competitiveness, it is 'essential to grant the [Single Resolution] Board necessary flexibility in tailoring the MREL requirements to the individual circumstances'. The Appeal Panel, on the contrary, held that it must confine itself to verify errors of law and manifest errors of assessment. ${ }^{133}$

Neither have the EASA, nor ACER BoAs avoided recourse to deferential review. The EASA BoA has explicitly referred in this respect to the problems of both empirical and normative uncertainty in the EASA decision-making. It highlighted the normative aspect that 'aviation safety is intimately linked to the protection of the life of humans', and linked it to the empirical one by noting that 'the EU regulation 'submits the issuance of an approval of flight conditions to only one condition, without any further qualifications. That condition is broadly drafted and it is that the agency must be satisfied that the aircraft is capable of safe flight'. ${ }^{134}$ When uncertainty persists, despite the arguments and evidence advanced by the appellant, the EASA BoA has no choice but to defer to the EASA. ${ }^{135}$

The ACER BoA, in turn, highlighted another reason for deferential review. It deals with decisions requiring a consideration of technical and economic issues alike, pertaining to the energy market in the EU Member States, moreover enmeshed with high-profile political controversies. ${ }^{136}$ This BoA considered that deferential review was indispensable given 'the limited timeframe it is given to decide on the appeal... and the principle of procedural economy'. Rather than second-guessing the ACER, the BoA 'limits itself to decide whether

${ }_{133}$ SRB Appeal Panel, Case 8/18, anonymised, para 30.

${ }^{134}$ EASA BoA, Case AP/01/2012 Heli-Flight GmbH, para. 62-63. In other words, what technical specifications an aircraft must have for the EASA to state that it is capable of safe flight is a matter of both normative uncertainty (what safe flight actually mean) and empirical uncertainty (which technical specifications match the abstract notion of 'being capable to safe flight'). The answer to this question depends on axiological preferences and the balance of values such as the protection of public security and interests of the aircraft industry, even if one maintains that the first one has absolute priority. The EASA needs also to consider other values such as the protection of the environment. See, EASA BoA, Case AP/06/2013 Issoire Aviation, paras 28 and 46-48.

135 For instance, ibid., para 11: 'in essence the Appellant calls upon the Board to decide which opinion is the better. The Board cannot see that the elements presented give it a basis for finding that the Agency is wrong. The view of the Agency is not invalidated because for instance [an aviation authority in another jurisdiction] would have taken a different view, or because some other instance considers a certain numer of flying hours sufficient to overcome the concerns that it may have.'

${ }^{136}$ See also, a recent dispute between Poland and Germany before the EGC in Case T-883/16 Poland v Commission. 
the Defendant made a manifest error of assessment'. ${ }^{137}$ Moreover, the ACER ECHA has highlighted that 'whereas the Agency's director has a full-time staff of technical experts and his disposal, the members of the Board of Appeal exercise these functions on a part-time basis, and they are selected precisely because of their current or former experience as staff of national or EU authorities in the energy sector. A Board of Appeal thus composed cannot be expected, nor was it intended, to replicate the in-depth assessment of highly complex technical issues...'. ${ }^{138}$ Despite this somewhat defensive rhetoric, a study of the ACER BoA decisions suggests that it thoroughly engages with the arguments opposing and supporting the decisions of ACER.

\section{Conclusion}

Due to the expanding field of EU regulatory action, normative and empirical epistemic uncertainty is likely to remain a crucial problem for EU administrative law and its 'steering capacity'. ${ }^{139}$ This problem relates to substantive and procedural law alike, including the mechanisms for judicial or extra-judicial review. Both the EU Courts and the proliferating BoAs attempt to reduce the level of epistemic uncertainty surrounding EU administrative action. A certain residual level of epistemic uncertainty is, however, unavoidable. Therefore, although the ECHA BoA has managed to delve into the intricacies of scientific problems, which the EU Courts may wish to leave to expert committees, focusing instead of ensuring their independence, it has not wholly eliminated deference, to the disappointment of some litigants. Other BoAs report facing similar problems as the generalist EGC: insufficient resources, time and access to expertise to improve their review technique.

The ongoing discussion regarding the thoroughness of judicial review, the legality challenges regarding the thoroughness of extra-judicial review, the disappointment with the lack of independent fact-finding within review proceedings in the name of objective truth-seeking, doubts regarding the adequacy of the adversarial system of pleas in the current context of epistemic uncertainty underpinning EU legal acts point to the existence

\footnotetext{
137 ACER BoA, Case A-002-2018 PRISMA European Capacity Platform GmbH, para 16. See also, Case A-001-2017 Energie Control Austria et al., paras 104-111; Case A-001-2018 AQUIND, paras 46 and 51-53.

138 ACER BoA, Case A-006-2019 Gaz-System, para 14.

${ }^{139}$ A concept proposed by Nehl (n. 13).
} 
of a much deeper and more structural controversy regarding how exactly judicial and extrajudicial review mechanisms could and should frame, orient and constrain the exercise of technical and political discretion. Is thorough and inquisitorial review a necessarily good thing? Where lies a boundary between review, founded upon the application of legal norms, and arbitrary second-guessing of value-judgments or partly subjective views on complex empirical issues?

At the domestic level, longer historical processes shaped the popular understanding and expectations as to the system of administrative justice. When it comes to the EU level, the ultimate purpose of judicial and extra-judicial review, and the procedural model for the realisation of this purpose, seem to be a matter of political choice to a much greater extent. In the current institutional context, this choice is left mainly to the EU judges themselves, who have the upper hand in shaping the EU procedural law, ${ }^{140}$ as well as to the management boards of the agencies or even the BoAs themselves.

We face uncertainty surrounding the meaning and realisation of the 'rule of law' with regard to administrative action based on normatively and empirically uncertain appraisals. If the rule of law implies a foundation of administrative action upon objective truth about the law and facts, how to proceed if the truth is unattainable? Judicial and extra-judicial review mechanisms seem still capable of reducing the level of uncertainty but so do procedural mechanisms implemented within the first-instance procedures, such as independent expert committees, internal review by a new set of experts, full transparency towards the affected parties and stakeholders and the like. The compartmentalisation of governance processes into disparate administrative, appellate, and judicial stages makes it more difficult to examine how different procedural mechanisms can complement each other in terms of overall institutional and procedural justice. In other words, the expectations towards judicial review should be co-determined by the opportunities offered by pre-ceding extra-judicial review and other administrative mechanisms. At the same time, the allocation of tasks and, consequently, resources to the respective stages of governance process depends on a political choice to a considerable extent, at least when it comes to the EU governance structure with its judicial and extra-judicial review system.

An important political choice has recently been to enlarge the EGC to deal with what seemed to be a growing backlog and an expanding and diversifying field of judicial review. A

\footnotetext{
${ }^{140}$ Krajewski (n. 42).
} 
question remains about the specific role of more specialised extra-judicial review at the EU level. Should the BoAs only limit the sheer number of complex cases reaching the EU Courts, or are they capable of fulfilling more significant tasks, provided that the law-makers equip them with sufficient resources, as well as perhaps broader and more diversified composition. Considering the presently substantial experience of the BoAs, the EU lawmakers, as well as scholars, should also consider whether the rule of law with regard to uncertain empirical and normative assessments requires a form of more inquisitorial review with independent fact-checking, rather than adversarial review based on partisan evidence, whether the task of more inquisitorial review should be assigned to the BoAs, or whether some alternative administrative mechanisms and tools would be adequate to reduce the level of uncertainty. 
Author: Michal Krajewski

Title: Judicial and Extra-Judicial Review:The Quest for Epistemic Certainty

iCourts Working Paper Series, No. 226, 2020

Publication date: 10/December/2020

URL: http://jura.ku.dk/icourts/working-papers/

(C) Author

iCourts Working Paper Series

ISSN: 2246-4891

Michal Krajewski, Postdoctoral Research Fellow, University of Copenhagen, $i$ Courts Centre of Excellence for International Courts

Email: Michal.krajewski@jur.ku.dk

The iCourts Online Working Paper Series publishes pre-print manuscripts on international courts, their role in a globalising legal order, and their impact on politics and society and takes an explicit interdisciplinary perspective.

Papers are available at http://jura.ku.dk/icourts/

iCourts

- The Danish National Research Foundation's Centre of Excellence for International Courts The Faculty of Law

University of Copenhagen

Karen Blixens Plads 16 
2300 Copenhagen S

E-mail: icourts@jur.ku.dk

Tel. +4535322626 